\title{
Optimasi Komposisi Kandungan Nutrisi Pakan Ikan Buatan dengan Menggunakan Fuzzy Linear Programming
}

\author{
Vera Devani \\ Prodi Teknik Industri, Fakultas Sains dan Teknologi, UIN SUSKA Riau \\ JL.HR. Soebrantas No. 155 Simpang Baru, Panam, Pekanbaru, 28293 \\ Email: veradevani@gmail.com
}

\begin{abstract}
ABSTRAK
Pakan ikan harus mengandung nutrisi sesuai dengan kebutuhan ikan. Kandungan nutrisi yang harus dimuat dalam pakan ikan yaitu protein, lemak, karbohidrat dan lemak. Dengan menggunakan metode Fuzzy Linear Programming dapat diketahui kebutuhan bahan baku dan nutrisi, kebutuhan ideal bahan baku dan nutrisi, penambahan yang diizinkan pada bahan baku dan nutrisi serta biaya yang diperlukan untuk pembuatan pakan ikan buatan. Berdasarkan hasil penelitian diperoleh kandungan nutrisi dalam $100 \mathrm{~kg}$ pakan ikan buatan yaitu 19,50 kg protein, 4,09 kg lemak, 17,02 kg karbohidrat, 9,75 kg serat dengan biaya Rp 98.795 serta dapat mengurangi biaya sebesar Rp 2.519,40 (2,50\%) jika dibandingkan menggunakan LinearProgramming.
\end{abstract}

Kata Kunci: Fuzzy Linear Programming, Linear Programming, Pakan Buatan

\section{Pendahuluan}

Keberhasilan dari suatu usaha budidaya ikan sangat ditentukan oleh tiga faktor yakni breeding (bibit), feeding (pakan), dan management.Jika dilihat dari total biaya produksi dalam usaha budidaya ikan maka kontribusi pakan adalah yang paling tinggi yakni sekitar $60 \%$ [3].

Pakan memiliki peranan yang sangat penting sebagai sumber energi untuk pemeliharaan tubuh, pertumbuhan dan perkembangbiakan ikan.Oleh sebab itu nutrisi yang terkandung dalam pakan ikan harus benar-benar terkontrol dan memenuhi kebutuhan dari ikan tersebut. Pemberian pakan ikan yang sesuai akan menghindarkan ikan dari berbagai serangan penyakit, khususnya penyakit nutrisi. Penyakit nutrisi dapat dihindari dengan pemberian kombinasi pakan alami dan pakan buatan dengan komposisi yang lengkap.

Biaya pakan pada budidaya ikan air tawar sangat tinggi. Peternak ikan harus melakukan penghematan pada komponen biaya pakan. Untuk menghemat biaya tersebut, peternak ikan dapat membuat pakan ikan sendiri dengan memanfaatkan sisa limbah, seperti kepala udang/ikan, bungkil kelapa sawit, bungkil kacang tanah, ampas tahu, dan lain sebagainya.

Linear Programming merupakan salah satu model yang dapat digunakan untuk menyelesaikan masalah optimasi. Permasalahan pada Linear Programming, dimodelkan secara tetap dengan menggunakan parameter-parameter yang umum digunakan. Pada Linear Programming keberadaan data dan formulasi yang digunakan sudah bersifat tertentu dan pasti.

Pada Fuzzy Linear Programming, akan dicari nilai fungsi objektif yang akan dioptimasikan sesuai dengan pembatas yang dimodelkan menggunakan himpunan fuzzy. Fungsi tujuan pada LinearProgramming tidak lagi benar-benar maksimum atau minimum karena ada beberapa hal yang perlu mendapat pertimbangan.Tanda pada pembatas pada kasus maksimasi dan minimasi tidak lagi bermakna crisp secara matematis, namun sedikit mengalami pelanggaran makna. Hal ini disebabkan karena adanya beberapa yang perlu dipertimbangkan dalam sistem yang mengakibatkan pembatas tidak dapat didekati secara tegas.

Penelitian dengan menggunakan metoda Fuzzy Linear Programming sudah banyak dilakukan terutama di bidang manufaktur. Penelitian tentang aplikasi Fuzzy Linear Programming untuk produksi bola lampu [8].Metode perencanaan produksi yang digunakan adalah metode Fuzzy Linear Programming dengan metode simpleks.Dengan menggunakan Fuzzy Linear Programming dapat diperoleh nilai optimum jumlah produk bola lampu yang diproduksi sesuai permintaan pasar dan sesuai dengan keterbatasan sumber daya produksi. Sumber daya yang diteliti adalah kapasitas produksi, waktu kerja, dan bahan baku. Tujuan penelitian adalah untuk menentukan jumlah bahan baku dan waktu kerja.

Penelitian lainnya tentang aplikasi Fuzzy Linear Programming dalam optimalisasi produksi [11]. Aplikasi Fuzzy Linear Programming digunakan untuk mengoptimalkan produksi jamu dan menentukan biaya produksi di PT Nyonya Meneer Semarang.

Penelitian di bidang manufaktur yang lain tentang aplikasi Fuzzy Linear Programming (FLP) dan simulasi Arena 10.0 untuk mengoptimalkan production planning [9]. Pada penelitian ini, hasil perhitungan optimasi menggunakan Linear Programming (LP) dan Fuzzy Linear Programming 
(FLP) diperoleh jumlah tiang pancang dan taing listrik yang diproduksi serta keuntungan optimum.

Penelitian tentang optimasi kandungan nutrisi pada pakan ikan sebelumnya telah dilakukan [2]. Metoda yang digunakan pada penelitian tersebut adalah Goal Programming. Variabel keputusan yang digunakan adalah enam (6) jenis bahan baku pakan ikan buatan, sedangkan fungsi pembatas kandungan nutrisi berupa protein, karbohidrat, dan lemak. Variabel respon (fungsi tujuan) yang diminimumkan adalah biaya dan batas atas kandungan nutrisi serta memaksimumkan batas bawah kandungan nutrisi.

Sebagai kelanjutan dari penelitian tersebut, dengan menggunakan metoda Fuzzy Linear Programming diteliti 8 (delapan) jenis bahan baku pakan ikan buatan dengan fungsi pembatas yaitu kandungan nutrisi berupa protein, karbohidrat, lemak, dan serat serta ketersediaan bahan baku pakan ikan buatan. Tujuan penelitian yang dilakukan adalah untuk menentukan kebutuhan bahan baku dan nutrisi,menentukan kebutuhan ideal bahan baku dan nutrisi, menentukan penambahan yang diizinkan pada bahan baku dan nutrisi sertamenentukan biaya optimal dan selisih biaya untuk pembuatan pakan ikan buatan jika dibandingkan dengan menggunakan Linear Programming.

\section{Tinjauan Pustaka}

\section{Pakan Buatan}

Pakan adalah pakan yang dibuat dengan formulasi tertentu berdasarkan pertimbangan kebutuhannya [3]. Pakan merupakan sumber energi dan materi bagi pertumbuhan dan kehidupan makhluk hidup. Zat yang terpenting dalam pakan adalah protein. Pakan berkualitas adalah pakan yang kandungan protein, lemak, karbohidrat, mineral dan vitaminnya seimbang.

Pakan buatan adalah campuran dari berbagai sumber bahan baku yang disusun secara khusus berdasarkan komposisi yang dibutuhkan untuk digunakan sebagai pakan [1]. Pakan buatan adalah makanan ikan yang dibuat dari campuran bahanbahan alami dan atau bahan olahan yang selanjutnya dilakukanproses pengolahan serta dibuat dalam bentuk tertentu sehingga tercipta daya tarik (merangsang) ikan untuk memakannya dengan mudah dan lahap[4]. Definisi lain mengatakan pakan buatan (artificial feed) adalah pakan yang sengaja disiapkan dan dibuat [7].

Jenis pakan ikan berdasarkan konstribusinya dalam menghasilkan penambahan berat badan dapat dikelompokkan menjadi dua yaitu [7]:

1. Pakan tambahan (suplementary feed), yaitu pakan yang digunakan untuk melengkapi kebutuhan ikan selain pakan alami. Konstribusipakan tambahan hanya menghasilkan penambahan berat badan kurang dari $50 \%$

2. Pakan lengkap (complete feed), yaitu pakan yang diberikan untuk menggantikan seluruh kebutuhan makanan ikan. Konstribusi pakan lengkap menghasilkan penambahan berat badan lebih dari $50 \%$.

Untuk mencukupi kebutuhan pakan ikan, cara yang paling praktis adalah dengan menggunakan pakan buatan. Beberapa keunggulan menggunakan pakan buatan adalah:

1. Lebih mudah diperoleh dalam jumlah cukup, tepat waktu, dan berkesinambungan.

2. Lebih tahan lama, minimum selama satu musim.

3. Kandungan gizinya dapat diatur dan disesuaikan dengan kebutuhan ikan yang akan diberikan makan.

4. Bentuk dan ukuran pakan buatan dapat diatur sesuai dengan ukuran ikan atau umur ikan.

5. Daya tahan di dalam air dapat diatur dan disesuaikan dengan kebiasaan makan ikan.

6. Bau, rasa, dan warna dapat diatur sehingga akan lebih menarik ikan-ikan yang diberi makan.

\section{Linear Programming}

Penerapan Linear Programming pada umumnya meliputi permasalahan pengalokasian sumber daya yang terbatas pada aktivitas yang saling bersaing untuk menghasilkan solusi yang optimal [5]. Pada Linear Programming, permasalahan di modelkan secara tetap dengan menggunakan parameter-parameter yang umum digunakan dan keberadaan data serta informasi yang digunakan juga sudah bersifat tertentu, pasti dan tidak menimbulkan ambiguitas [6].

Model matematis dari Linear Programming adalah sebagai berikut [10]:

Maksimumkan (minimumkan):

Pembatas:

$$
Z=c_{1} X_{1}+c_{2} X_{2}+\cdots+c_{n} X_{n}
$$

$a_{11} X_{1}+a_{12} X_{2}+\cdots+a_{1 n} X_{n} \leq b_{1}$

$a_{21} X_{1}+a_{22} X_{2}+\cdots+a_{2 n} X_{n} \leq b_{2}$

$a_{m 1} X_{1}+a_{m 2} X_{2}+\cdots+a_{m n} X_{n} \leq b_{m}$

$X_{1} \geq 0, X_{2} \geq 0, \ldots \ldots X_{n} \geq 0$

dimana:

$X_{j}$ : variabel keputusan

$a_{i j}$ : koefisien teknologi

$c_{j}$ : koefisien fungsi tujuan

$b_{i}$ : koefisien sisi kanan

\section{Logika Fuzzy}

Fuzzy secara bahasa diartikan sebagai kabur atau samar-samar[6]. Dalam fuzzy dikenal derajat keanggotaan yang memiliki rentang nilai 0 (nol) hingga 1 (satu). Berbeda dengan himpunan tegas yang memiliki nilai 1 atau 0 (ya atau tidak).

Logika Fuzzy merupakan suatu logikayang memiliki nilai kekaburan atau kesamaran 
(fuzzyness) antara benar atau salah [6]. Dalam teori Logika Fuzzy suatu nilai bisa bernilai benar atau salah secara bersamaan.Namun seberapa besar kebenaran dan kesalahan itu tergantung pada bobot keanggotaan yang dimilikinya. Logika Fuzzymemiliki derajat keanggotaan dalam rentang 0 hingga 1.

Beberapa alasan mengapa orang menggunakan Logika Fuzzy, antara lain [6]:

1. Konsep Logika Fuzzy mudah dimengerti. Konsep matematis yang mendasari penalaran fuzzy sangat sederhana dan mudah dimengerti.

2. Logika Fuzzy sangat fleksibel, artinya mampu beradaptasi dengan perubahan-perubahan, dan ketidakpastian yang menyertai permasalahan.

3. Logika Fuzzy memiliki toleransi terhadap datadata yang tidak tepat.

4. Logika Fuzzy mampu memodelkan fungsifungsi nonlinier yang sangat kompleks.

5. Logika Fuzzy dapat membangun dan mengaplikasikan pengalaman-pengalaman para pakar secara langsung tanpa harus melalui proses pelatihan.

6. Logika Fuzzy dapat bekerja sama dengan teknikteknik kendali secara konvensional.

7. Logika fuzzy menggunakan bahasa sehari-hari sehingga mudah dimengerti.

\section{Fuzzy Linear Programming}

Model Linear Programming klasik adalah [6]:

\section{Maksimumkan:}

Pembatas:

$$
f(x)=c^{T} x
$$

$$
\begin{aligned}
& A x \leq b \\
& x \geq 0
\end{aligned}
$$

dengan $\mathrm{c}, \mathrm{x} \varepsilon \mathrm{R}^{\mathrm{n}}, \mathrm{b} \varepsilon \mathrm{R}^{\mathrm{m}}, \mathrm{A} \varepsilon \mathrm{R}^{\mathrm{nxm}}$

\section{Minimumkan:}

Pembatas:

$$
f(x)=c^{T} x
$$

$$
\begin{aligned}
& A x \geq b \\
& x \geq 0
\end{aligned}
$$

dengan $\mathrm{c}, \mathrm{x} \varepsilon \mathrm{R}^{\mathrm{n}}, \mathrm{b} \varepsilon \mathrm{R}^{\mathrm{m}}, \mathrm{A} \varepsilon \mathrm{R}^{\mathrm{nxm}}$.

A, b, c adalah bilangan crips, tanda $\leq$ untuk kasus maksimasi dan tanda $\geq$ untuk kasus minimasi juga bermakna crips, demikian juga perintah maksimumkan dan minimumkan merupakan bentuk imperatif tegas.

Fungsi keanggotaan untuk model keputusan himpunan fuzzy dapat dinyatakan sebagai berikut[6]:

$$
\max _{\mathrm{x} \geq 0} \mu_{D}[B x]=\max \min \left\{\mu_{i}\left[B_{i} x\right]\right\}
$$

Terlihat bahwa $\mu_{\mathrm{i}}\left(\mathrm{B}_{\mathrm{i}} \mathrm{x}\right)=0$ jika batasan ke-i benarbenar dilanggar. Sebaliknya, $\mu_{\mathrm{i}}\left(\mathrm{B}_{\mathrm{i}} \mathrm{x}\right)=1$ jika batasan ke-i benar-benar dipatuhi (atau sama halnya dengan batasan yang bernilai tegas). Nilai $\mu_{\mathrm{i}}(\mathrm{Bx})$ akan naik secara monoton pada selang $[0,1]$.

$$
\begin{aligned}
& \mu_{\mathrm{i}}\left[B_{i} x\right]=\left\{\begin{array}{cc}
1 ; & \text { jika } B_{\mathrm{i}} \mathrm{x} \leq \mathrm{d}_{\mathrm{i}} \\
\epsilon[0,1] ; & \text { jika di }<B_{i} \mathrm{x} \leq \mathrm{d}_{\mathrm{i}}+\mathrm{p}_{\mathrm{i}} \\
0 ; & \text { jika } \mathrm{B}_{\mathrm{i}} \mathrm{x}>\mathrm{d}_{\mathrm{i}}+\mathrm{p}_{\mathrm{i}}
\end{array}\right\} \\
& \mathrm{i}=0,1,2,3, \ldots \text { m. }
\end{aligned}
$$

Gambar 1 menunjukan fungsi keanggotaan himpunan fuzzy [6].

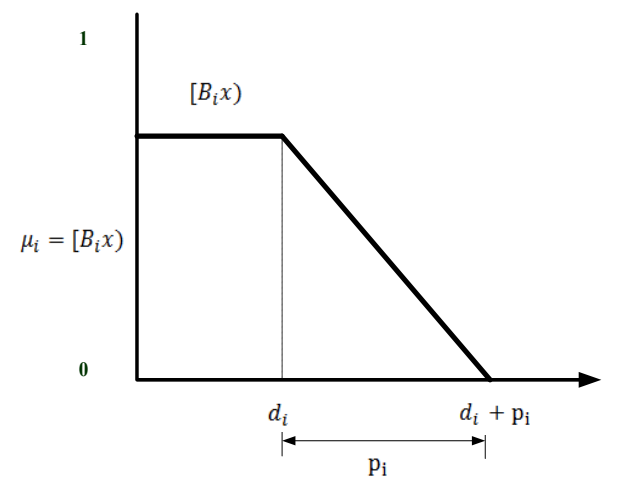

Gambar 1 Fungsi Keanggotaan

$$
\begin{aligned}
& \mu_{\mathrm{i}}[\mathrm{x}]=\left\{\begin{array}{c}
1 ; \quad \text { jika } \mathrm{B}_{\mathrm{i}} \mathrm{x} \leq \mathrm{d}_{\mathrm{i}} \\
1-\frac{\mathrm{B}_{\mathrm{x}} \mathrm{x}-\mathrm{d}_{\mathrm{i}}}{\mathrm{p}_{\mathrm{i}}} ; \\
0 ; \quad \text { jika } \text { di }<\mathrm{B}_{\mathrm{i}} \mathrm{x} \leq \mathrm{d}_{\mathrm{i}}+\mathrm{p}_{\mathrm{i}}
\end{array}\right\} \\
& \mathrm{i}=0,1,2,3, \ldots . \mathrm{m} .
\end{aligned}
$$

$\mathrm{p}_{\mathrm{i}}$ adalah toleransi interval yang diperbolehkan untuk melakukan pelanggaran baik pada fungsi objektif maupun batasan.Sehingga untuk mencari $\lambda$ cut dapat dihitung sebagai $\lambda=1-t$, dengan:

$$
\mathrm{d}_{\mathrm{i}}+\mathrm{tp}_{\mathrm{i}}=\text { ruas kanan batasan ke-i }
$$

Dengan demikian diperoleh bentuk Linear Programmingbaru sebagai berikut [6]:

\section{Maksimumkan:}

\section{$\lambda$}

\section{Pembatas:}

$$
\begin{aligned}
& \quad \lambda p_{i}+B_{i} x \leq d_{i}+p_{i} \\
& \mathrm{i}=0,1,2,3, \ldots, \mathrm{m} \\
& x \geq 0
\end{aligned}
$$

\section{Metode Penelitian}

Pada penelitian ini, data diperoleh melalui survey di lapangan dan studi literatur. Data yang digunakan adalah jenis bahan baku pakan ikan buatan, ketersediaan setiap jenis bahan baku, harga perkg setiap jenis bahan baku, kandungan nutrisi, persentase kebutuhan nutrisi, dan persentase 
minimum kandungan nutrisi. Langkah-langkah dalam pengolahan data adalah sebagai berikut:

1. Mendefinisikan variabel

Pada pendefinisian variabel ini dilakukan penguraian variabel-variabel keputusan.

2. Formulasi model Linear Programming dengan konsep fuzzy $\mathrm{t}=0$ dan $\mathrm{t}=1$.

Setelah dilakukan pendefinisian variabel keputusan, maka dilanjutkan dengan memformulasikan model Linear Programming dengan konsep fuzzy $\mathrm{t}=0$ dan $\mathrm{t}=1$ dengan fungsi tujuan minimasi.

2. Formulasi model Fuzzy Linear Programming Setelah memformulasikan model Linear Programming kemudian dilanjutkan dengan memformulasikan model Fuzzy Linear Programming dengan fungsi tujuan maksimasi.

3. Mencari solusi optimal Langkah berikutnya adalah pengolahan data untuk mencari solusi yang optimal dari formulasi Linear Programmingdengan konsep fuzzy $\mathrm{t}=0$ dan $\mathrm{t}=1$ dengan menggunakan software QM 2.1. sedangkan untuk Fuzzy Linear Programming dengan menggunakan software Lindo 6.1.

\section{Hasil dan Pembahasan}

\section{Model Linear Programming}

Varibel keputusan adalah simbol matematika yang menggambarkan tingkatan aktivitas.Variabel keputusan untuk model Linear Programming untuk bahan baku pakan ikan buatan adalah sebagai berikut:

$\mathrm{X}_{1}$ : Kandungan nutrisi tepung jagung

$\mathrm{X}_{2}$ : Kandungan nutrisi tepung kepala udang

$\mathrm{X}_{3}$ : Kandungan nutrisi tepung bekicot

$\mathrm{X}_{4}$ : Kandungan nutrisi ampas tahu

$\mathrm{X}_{5}$ : Kandungan nutrisi dedak padi

$\mathrm{X}_{6}$ : Kandungan nutrisi bungkil kelapa

$\mathrm{X}_{7}$ : Kandungan nutrisi tepung gaplek

$\mathrm{X}_{8}$ : Kandungan nutrisi tepung beras

Fungsi tujuan merupakan hubungan matematika linear yang menjelaskan tujuan dalam terminologi variabel keputusan.Fungsi tujuan dalam penelitian ini adalah mengoptimalkan biaya.

Formulasi model matematik Linear

Programmming pada penelitian ini adalah:

Minimumkan:

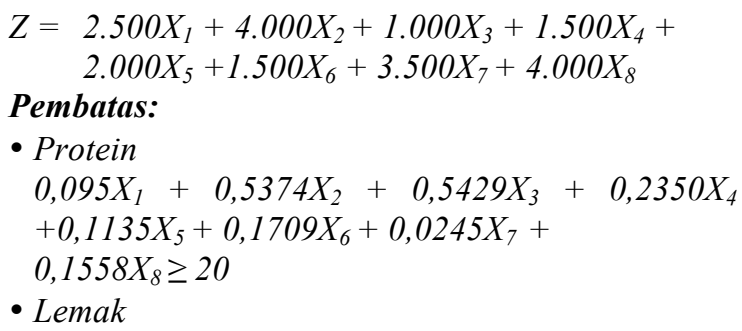

$0,0195 X_{1}+0,0665 X_{2}+0,0418 X_{3}+0,0540 X_{4}+$

$0,1215 X_{5}+0,0944 X_{6}+0,0143 X_{7}+0,0120 X_{8} \geq 4$

- Karbohidrat

$0,7172 X_{1}+0,3045 X_{3}+0,2692 X_{4}+0,2862 X_{5}+$ $0,2377 X_{6}+0,7612 X_{7}+0,3473 X_{8} \geq 20$

- Serat

$0,0537 X_{1}+0,1461 X_{2}+0,0105 X_{3}+0,1703 X_{4}+$

$0,2446 X_{5}+0,3040 X_{6}+0,0460 X_{7}+$

$0,1073 X_{8} \geq 10$

- Tepung jagung

$X_{1} \leq 10$

- Tepung kepala udang

$X_{2} \leq 5$

- Tepung bekicot

$X_{3} \leq 20$

- Ampas tahu

$X_{4} \leq 20$

- Dedak padi

$X_{5} \leq 15$

- Bungkil kelapa

$X_{6} \leq 15$

- Tepung gaplek

$X_{7} \leq 10$

- Tepung beras

$X_{8} \leq 5$

$X_{1}, X_{2}, X_{3}, X_{4}, X_{5}, X_{6}, X_{7}, X_{8} \geq 0$

\section{Model Linear Programming dengan Konsep Logika Fuzzy}

Dengan menggunakan konsep Logika Fuzzy, maka terdapat dua kemungkinan nilai toleransi untuk kandungan nutrisi, yaitu:

1. Nilai $\mathrm{t}=0$, mengindikasikan bahwa bahan baku pada pakan ikan buatan tidak membutuhkan penambahan kandungan nutrisi.

2. Nilai $\mathrm{t}=1$, mengindikasikan bahwa bahan baku pada pakan ikan buatan membutuhkan penambahan kandungan nutrisi.

Dengan adanya nilai toleransi interval ini, maka persamaan pembatas (constrains) untuk setiap kandungan nutrisi akan mengalami perubahan yaitu ditambahkan dengan nilai pembatas Fuzzy.

Berdasarkan fungsi tujuan dan pembatas (constrains) persamaan di atas, maka Model Linear Programming dengan konsep Logika Fuzzy untuk pakan ikan buatan adalah:

\section{Minimumkan:}

$Z=2.500 X_{1}+4.000 X_{2}+1.000 X_{3}+1.500 X_{4}+$

Pembatas:

$$
2.000 X_{5}+1.500 X_{6}+3.500 X_{7}+4.000 X
$$

$0,095 X_{1}+0,5374 X_{2}+0,5429 X_{3}+0,2350 X_{4}$

$+0,1135 X_{5}+0,1709 X_{6}+0,0245 X_{7}+$

$0,1558 X_{8} \geq 20-t$

$0,0195 X_{1}+0,0665 X_{2}+0,0418 X_{3}+0,0540 X_{4}+$

$0,1215 X_{5}+0,0944 X_{6}+0,0143 X_{7}+$

$0,0120 X_{8} \geq 4-0,2 t$ 
$0,7172 X_{1}+0,3045 X_{3}+0,2692 X_{4}+0,2862 X_{5}+$ $0,2377 X_{6}+0,7612 X_{7}+$

$0,3473 X_{8} \geq 20-t$

$0,0537 X_{1}+0,1461 X_{2}+0,0105 X_{3}+0,1703 X_{4}+$

$0,2446 X_{5}+0,3040 X_{6}+0,0460 X_{7}+$

$0,1073 X_{8} \geq 10-0,5 t$

$X_{1} \leq 10-0,5 t$

$X_{2} \leq 5-0,25 t$

$X_{3} \leq 20-t X_{4} \leq 20-t$

$X_{5} \leq 15-0,75 t$

$X_{6} \leq 15-0,75 t$

$X_{7} \leq 10-0,5 t$

$X_{8} \leq 5-0,25 t$

$X_{1}, X_{2} \geq 0$

Dengan menggunakan software $Q M \quad 2.1$ diperoleh output model Linear Programming dengan konsep Logika Fuzzy $(\mathrm{t}=0, \boldsymbol{\lambda}=1)$ adalah sebagai berikut:

Tabel 1 Output Model Linear Programming dengan Konsep Logika Fuzzy $(\mathrm{t}=0, \boldsymbol{\lambda}=1)$

\begin{tabular}{|c|c|c|}
\hline \multicolumn{2}{|l|}{ ( Solution list } & $=\square \times$ \\
\hline \multicolumn{3}{|c|}{ (untitled) Solution } \\
\hline Variable & Status & Value \\
\hline Tepung jagung (X1) & Basic & 4.7097 \\
\hline Tepung kepala udang (X2) & Basic & 1.495 \\
\hline Tepung bekicot (X3) & Basic & 20 \\
\hline Ampas tahu (X4) & Basic & 20 \\
\hline Dedak padi (X5) & Basic & 5.5301 \\
\hline Bungkil kelapa (X6) & Basic & 15 \\
\hline Tepung gaplek (X7) & NONBasic & 0 \\
\hline Tepung beras $(x 8)$ & NONBasic & 0 \\
\hline surplus 1 & NONBasic & 0 \\
\hline surplus 2 & Basic & 0.1952 \\
\hline surplus 3 & NONBasic & 0 \\
\hline surplus 4 & NONBasic & 0 \\
\hline slack 5 & Basic & 5.2903 \\
\hline slack 6 & Basic & 3.505 \\
\hline slack 7 & NONBasic & 0 \\
\hline slack 8 & NONBasic & 0 \\
\hline slack 9 & Basic & 9.4699 \\
\hline slack 10 & NONBasic & 0 \\
\hline slack 11 & Basic & 10 \\
\hline slack 12 & Basic & 5 \\
\hline Optimal Value (Z) & & $101,314.4$ \\
\hline 1 & & . \\
\hline
\end{tabular}

Dengan menggunakan software QM 2.1 diperoleh output model Linear Programming dengan konsep Logika Fuzzy $(\mathrm{t}=1, \boldsymbol{\lambda}=0)$ adalah sebagai berikut:
Tabel 2 Output Model Linear Programming dengan Konsep Logika Fuzzy $(\mathrm{t}=1, \boldsymbol{\lambda}=0)$

\begin{tabular}{|l|r|r|}
\hline \multicolumn{3}{|c|}{ (untitled) Solution } \\
\hline \multicolumn{3}{|c|}{ Solution list } \\
\hline Variable & Status & Value \\
\hline & \multicolumn{1}{|c|}{ Basic } & 4.4742 \\
\hline Tepung jagung (X1) & Basic & 1.4202 \\
\hline Tepung kepala udang (X2) & Basic & 19. \\
\hline Tepung bekicot (X3) & Basic & 19. \\
\hline Ampas tahu (X4) & Basic & 5.2536 \\
\hline Dedak padi (X5) & Basic & 14.25 \\
\hline Bungkil kelapa (X6) & NONEasic & 0. \\
\hline Tepung gaplek (X7) & NONEasic & 0. \\
\hline Tepung beras (X8) & NONEasic & 0. \\
\hline surplus 1 & Basic & 0.1854 \\
\hline surplus 2 & NONEasic & 0. \\
\hline surplus 3 & NONEasic & 0. \\
\hline surplus 4 & Basic & 5.0258 \\
\hline slack 5 & Basic & 3.3298 \\
\hline slack 6 & NONEasic & 0. \\
\hline slack 7 & NONEasic & 0. \\
\hline slack 8 & Basic & 8.9964 \\
\hline slack 9 & NONEasic & 0. \\
\hline slack 10 & Basic & 9.5 \\
\hline slack 11 & Basic & 4.75 \\
\hline slack 12 & & $96,248.7$ \\
\hline Optimal Value (Z) & & \\
\hline \hline
\end{tabular}

\section{Model Fuzzy Linear Programming}

Langkah awal sebelum membuat model Fuzzy Linear Programming adalah mencari nilai $\mathrm{p}_{0}$. Nilai $\mathrm{p}_{\mathrm{o}}$ adalah hasil dari pengurangan antara $\mathrm{Z}$ pada saat $\mathrm{t}=1$ dan $\mathrm{Z}$ pada saat $\mathrm{t}=0$, sehingga diperoleh nilai $\mathrm{p}_{0}$ :

$$
\begin{aligned}
\mathrm{p}_{0} & =101.314,4-96.248,7 \\
& =5.065,7
\end{aligned}
$$

Tujuan dari pembentukan model Fuzzy Linear Programming ini adalah untuk mencari nilai antara 0 dan 1 yang merupakan konsep dari logika Fuzzy yang memiliki nilai yang optimal. Pada Fuzzy Linear Programming, nilai tersebut dilambangkan dengan $\lambda$. Sehingga Formulasi umum dari model Fuzzy Linear Programming menjadi:

\section{Fungsi tujuan:}

\section{Pembatas:}

Maksimumkan $Z=\lambda$

$5.065,7 \lambda+2.500 X_{1}+4.000 X_{2}+1.000 X_{3}+1.500 X_{4}$ $+2.000 X_{5}+1.500 X_{6}+3.500 X_{7}+4.000 X_{8} \leq$

\subsection{4 .4}

$-\lambda+0,0950 X_{1}+0,5374 X_{2}+0,5429 X_{3}+0,2350 X_{4}$

$+0,1135 X_{5}+0,1709 X_{6}+0,0245 X_{7}+$

$0,1558 X_{8} \geq 19$

$-0,2 \lambda+0,0195 X_{1}+0,0665 X_{2}+0,0418 X_{3}+$

$0,0540 X_{4}+0,1215 X_{5}+0,0944 X_{6}+0,0143 X_{7}+$

$0,0120 X_{8} \geq 3,8$ 
$-\lambda+0,7172 X_{1}+0,3045 X_{3}+0,2692 X_{4}+0,2862 X_{5}$

$+0,2377 X_{6}+0,7612 X_{7}+0,3473 X_{8} \geq 19$

$-0,5 \lambda+0,0537 X_{1}+0,1461 X_{2}+0,0105 X_{3}+$

$0,1703 X_{4}+0,2446 X_{5}+0,3040 X_{6}+0,0460 X_{7}+$

$0,1073 X_{8} \geq 9.5$

$-0,5 \lambda+X_{1} \leq 9,5-0,25 \lambda+X_{2} \leq 4,75$

$-\lambda+X_{3} \leq 19-\lambda+X_{4} \leq 19-0,75 \lambda+X_{5} \leq 14,25-0,75 \lambda$

$+X_{6} \leq 14,25-0,5 \lambda+X_{7} \leq 9,5-0,25 \lambda+X_{8} \leq 4,75$

$\lambda, X_{1}, X_{2}, X_{3}, X_{4}, X_{5}, X_{6}, X_{7}, X_{8} \geq 0$

Dengan menggunakan software Lindo

6.1 diperoleh output sebagai berikut:

Tabel 3 Output Model Fuzzy Linear Programming

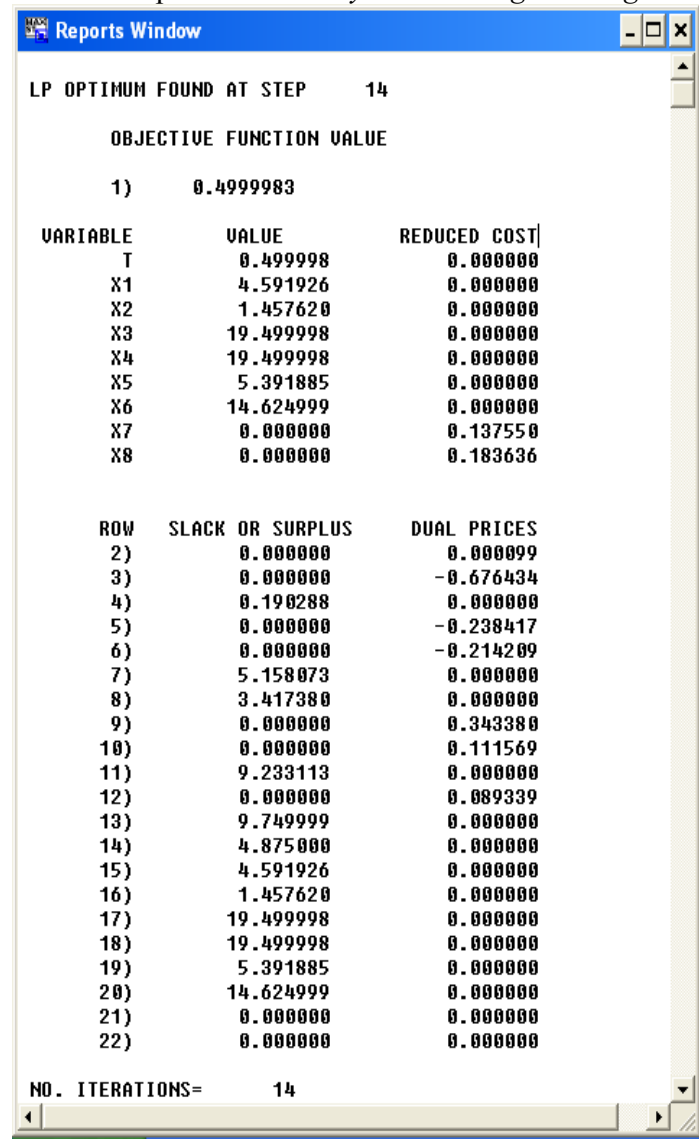

Perbandingan kebutuhan nutrisi dan bahan baku pakan ikan buatan model Linear Programmingdengan Konsep Logika Fuzzy untuk t $=0 \quad(\lambda=1)$ dan $\mathrm{t}=1 \quad(\lambda=0)$ dapat dilihat pada Tabel 4.
Tabel 4. Perbandingan Kebutuhan Nutrisi dan Bahan Baku Pakan Ikan Buatan Model Linear Programmingdengan Konsep Logika Fuzzy untuk t $=0$ $(\lambda=1)$ dan $\mathrm{t}=1 \quad(\lambda=0)$

\begin{tabular}{clccc} 
No. & Keterangan & Ketersediaan & $\begin{array}{c}\text { Kebutuhan } \\
\mathrm{t}=0, \lambda=1 \\
(\mathrm{~kg})\end{array}$ & $\begin{array}{c}\text { Kebutuhan } \\
\mathrm{t}=1, \lambda=0 \\
(\mathrm{~kg})\end{array}$ \\
\hline 1 & Protein & 20 & 20 & 19 \\
2 & Lemak & 4 & 4,2 & 3,98 \\
3 & Karbohidrat & 20 & $(4.87)$ & 16,58 \\
4 & Serat & 10 & 4,71 & 9,5 \\
5 & Tepung & 10 & & 4,47 \\
& jagung & & 1,50 & 1,42 \\
6 & Tepung & 5 & & \\
& kepala & & 20 & 19 \\
& udang & & & \\
7 & Tepung & 20 & 20 & 19 \\
& bekicot & & 5,53 & 5,25 \\
8 & Ampas tahu & 20 & 15 & 14,25 \\
9 & Dedak padi & 15 & & \\
10 & Bungkil & 15 & &
\end{tabular}

Kebutuhan nutrisi dan bahan baku pakan ikan buatan model Fuzzy Linear Programming dengan $\lambda=0,5$ dapat dilihat pada Tabel 5 .

Tabel 5 Kebutuhan Nutrisi dan Bahan Baku Pakan Ikan Buatan Fuzzy Linear Programming $\lambda=0,5$

\begin{tabular}{|c|c|c|c|c|}
\hline No. & Keterangan & $\begin{array}{c}\text { Kebutuhan } \\
\text { pada } \lambda=0,5 \\
(\mathrm{~kg})\end{array}$ & $\begin{array}{c}\text { Derajat } \\
\text { Keanggotaan }\end{array}$ & $\begin{array}{c}\text { Kebutuhan } \\
\text { Ideal } \\
(\mathrm{kg})\end{array}$ \\
\hline 1 & Protein & 19,50 & 1 & 19 \\
\hline 2 & Lemak & 4,09 & 0,05 & 3,99 \\
\hline 3 & Karbohidrat & 17,02 & 1 & 19 \\
\hline 4 & Serat & 9,75 & 1 & 9,5 \\
\hline 5 & $\begin{array}{l}\text { Tepung } \\
\text { jagung }\end{array}$ & 4,59 & 1 & 9,50 \\
\hline 6 & $\begin{array}{l}\text { Tepung } \\
\text { kepala } \\
\text { udang }\end{array}$ & 1,46 & 1 & 4,75 \\
\hline 7 & $\begin{array}{l}\text { Tepung } \\
\text { bekicot }\end{array}$ & 19,50 & 1 & 19 \\
\hline 8 & Ampas tahu & 19,50 & 1 & 19 \\
\hline 9 & Dedak padi & 5,39 & 1 & 14,5 \\
\hline 10 & $\begin{array}{l}\text { Bungkil } \\
\text { kelapa }\end{array}$ & 14,62 & 1 & 14,25 \\
\hline
\end{tabular}

Berdasarkan Tabel 4 dan 5, dapat dilihat sumber daya yang jumlahnya berlebih dan berkurang. Untuk dapat mengetahui jumlah penambahan sumber daya yang ketersediaannya kurang adalah dengan menggunakan nilai $\lambda$. Nilai $\lambda$ $=0,5$ mengandung pengertian bahwa $\lambda$ cut untuk setiap himpunan yang digunakan untuk mengimplementasikan setiap batasan sebesar 0,5. Dengan kata lain, skala terbesar $\mathrm{t}=1-0,5=0,5$, digunakan untuk menentukan besarnya penambahan terbesar dari setiap batasan yang diizinkan.

Berdasarkan pada Tabel 5, maka penambahan yang diizinkan selain yang memiliki derajat keanggotaan bernilai 1. Dengan demikian, penambahan yang diizinkan hanya untuk nutrisi lemak, nilai derajat keanggotaan 0,05. Derajat 
keanggotaan yang bernilai 1 tidak perlu dilakukan penambahan karena ketersediaan sudah mencukupi.

\section{Kesimpulan}

Dengan menggunakan metoda Fuzzy Linear Programming $\boldsymbol{\lambda}=0,5$ diperoleh:

1. Kebutuhan bahan baku pakan ikan buatan adalah:

\begin{tabular}{clc}
\hline No. & Keterangan & $\begin{array}{c}\text { Kebutuhan } \\
(\mathrm{kg})\end{array}$ \\
\hline 1 & Tepung jagung & 4,59 \\
2 & Tepung kepala udang & 1,46 \\
3 & Tepung bekicot & 19,50 \\
4 & Ampas tahu & 19,50 \\
5 & Dedak padi & 5,39 \\
6 & Bungkil kelapa & 14,62 \\
\hline
\end{tabular}

2. Kandungan nutrisi pada bahan baku pakan ikan buatan adalah:

\begin{tabular}{clc}
\hline No. & Keterangan & $\begin{array}{c}\text { Kebutuhan } \\
(\mathrm{kg})\end{array}$ \\
\hline 1 & Protein & 19,50 \\
2 & Lemak & 4,09 \\
3 & Karbohidrat & 17,02 \\
4 & Serat & 9,75 \\
\hline
\end{tabular}

3. Kebutuhan ideal setiap nutrisi dan bahan baku pakan ikan buatan adalah:

\begin{tabular}{clc}
\hline No. & Keterangan & $\begin{array}{c}\text { Kebutuhan } \\
(\mathrm{kg})\end{array}$ \\
\hline 1 & Protein & 19,50 \\
2 & Lemak & 3,99 \\
3 & Karbohidrat & 19 \\
4 & Serat & 9,5 \\
5 & Tepung jagung & 9,50 \\
6 & Tepung kepala udang & 4,75 \\
7 & Tepung bekicot & 19 \\
8 & Ampas tahu & 19 \\
9 & Dedak padi & 14,5 \\
10 & Bungkil kelapa & 14,25 \\
\hline
\end{tabular}

4. Penambahan yang diizinkan untuknutrisi lemak sebesar $0,1 \mathrm{~kg}$.

5. Dengan menggunakan Fuzzy Linear $\operatorname{Programming}(\lambda=0,5)$ biaya yang harus dikeluarkan sebesar Rp 98.795 (Rp 2.519,4 lebih kecil dibandingkan dengan hasil Linear Programming). Berarti dengan menggunakan metoda Fuzzy Linear Programming dapat meminimumkan biaya bahan baku pembuatan pakan ikan buatan sebesar $2,50 \%$.

\section{Daftar Pustaka}

[1] Afrianto, E. dan Evi L. 2005. Pakan Ikan, Kanisius. Yogyakarta.
[2] Devani, V. dan Sri B. Optimasi Kandungan Nutrisi Pakan Ikan Buatan dengan Menggunakan Multi Objective (Goal) Programming Model. Jurnal Sains, Teknologi dan Industri. Vol. 12, No. 2, Juni 2015, pp.255-261.

[3] Dharmawan, B. 2012. Usaha Pembuatan Pakan Ikan Konsumsi, Pustaka Baru Press. Yogyakarta.

[4] Djarijah, A. S. 1996. Pakan Ikan Alami. Kanisius, Yogyakarta.

[5] Hiller, F. S. dan Gerald J. L. 1990. Pengantar Riset Operasi. Erlangga. Jakarta.

[6] Kusumadewi, S. dan Hari P. 2010. Aplikasi Logika Fuzzy. Graha Ilmu. Yogyakarta.

[7] Mudjiman, A. 2011. Pakan Ikan. Penebar Swadaya. Depok.

[8] Suantio, H., A. Jabbar M. R., Ikhsan S. Aplikasi Fuzzy Linear Programming untuk Produksi Bola Lampu di PT XYZ. e-Jurnal Teknik Industri FT USU Vol 2, No. 2, Juni 2013. pp. 42-46.

[9] Suseno, Ari Z. A.Aplikasi Fuzzy Linear Programming (FLP) dan SimulasiArena 10.0 untuk Mengoptimalkan Production Planning.J@TI Undip. Vol. IX, No. 3, September 2014. Pp.147-150.

[10] Tarliah, T. dan Ahmad D. 2006.Operations Research. Sinar Baru. Bandung.

[11] Yulianto, A.W., Hardi S, dan Mashuri. Aplikasi Fuzzy Linear Programming Produksi dalam Optimalisasi Produksi. UNNES Journal of Mathematics. Vol. 1, No. 1. 2012. pp. 8-14. 